\title{
ASSESSING THE ROLE OF FOOD SELF-SUFFICIENCY AND FOOD SECURITY IN DIVERSIFICATION TOWARDS HIGH VALUE CROPS
}

\author{
Dr. Shazia Banu \\ Research Associate, Department of Economics, Lalit Narayan Mithila University - Darbhanga, Bihar, \\ India
}

DOI: 10.46609/IJSSER.2020.v05i08.016 URL: https://doi.org/10.46609/IJSSER.2020.v05i08.016

\begin{abstract}
The agriculture diversification is viewed as a strategy of allocation of more resources towards high value crops relative to subsistence or staple food crops. The rationale for diversification is that the returns are higher for the production of high value crops than for staple food. The households would diversify and the income generated can be used to meet the household food and other requirements. The land allocation decisions are micro level decisions and the linkages between food self-sufficiency, food security and diversification are complex. The study explores the relation between household food self-sufficiency, food security and diversification towards commercial crops. The results of the study show that household that are self-sufficient allocate higher proportion of area to high value crops than households which are food deficient. Nonfarm income helps the household to meet the food requirements and improves food security status. Households that are food secure have higher propensity to diversify towards cash crops. It implies that food self-sufficiency and food security has a positive and favorable influence in resource allocation towards cash crops.
\end{abstract}

Keywords: Diversification, High Value Crops, Food Self-Sufficiency, Food Security, Income, Consumption.

\section{Introduction}

The agriculture diversification is viewed as a strategy of allocation of more resources towards high value crops relative to subsistence or staple food crops. The rationale for diversification is that the returns are higher for the production of high value crops than for staple food. The households would diversify and the income generated can be used to meet the household food and other requirements. The allocation of resources is based on assumption that market exists for exchange of commodities produced and those needed for household food security. But markets may not exist or may be incomplete for every commodity produced or needed. The household 


\section{International Journal of Social Science and Economic Research}

ISSN: $2455-8834$

Volume:05, Issue:08 "August 2020"

cannot rely on markets for meeting their food requirements. The household may prefer the food self-sufficiency over increased returns from diversification. The household non-farm income also influences the food security and land allocation decisions. The linkages between food selfsufficiency, food security and diversification are complex. The study explores the relation between household food self-sufficiency, food security and diversification towards commercial crops. The primary research question is:

i. Is staple crop self-sufficiency necessary for diversification towards high value crops?

ii. How does the food self-sufficiency and food security influence the diversification towards cash crops?

The relationship between agriculture diversification, food self-sufficiency and food security has been documented in a number of studies. In literature, the subsistence cropping strategy is generally viewed as a food self-sufficiency strategy. However the incomplete markets and threat to food security may sometimes make it as the only viable strategy. The self-sufficiency strategy is guided by households concern for attainment of food security. The risk-averse households choose this strategy to guarantee their food security. The only incentive for this group of household towards diversification is that the marginal benefit of diversification exceeds marginal cost (Featherstone and Moss, 1990). Various empirical studies concluded that households in developing countries in order to maintain food security allocate significant resources to subsistence crops and then participate in high value crops or cash crops (Von Braun, 1994; Jayne, 1994; Govereh and Jayne 2003; and Joshi et al., 2003).

The study is based on household cross-sectional data from two villages of North Bihar. The North Bihar is dominant agriculture belt and the surveyed villages are from Darbhanga district, located at the core of this agricultural region. Two villages namely Dhamsain (Village I) and Kursoo (Village II) are selected based on their centrality and representative character of agriculture production of both the food and cash crops respectively. This agriculture belt is dominant in production of food crops mainly rice and wheat and some cash crops like litchi, mango and mustard. Although vegetables are important cash crops, these are cultivated at subsistence level mainly to satisfy the household's requirements. One hundred samples are drawn from each village by stratified and proportional random sampling approach. The selected households are agricultural households. Apart from income generated by sale of crops, the labour (wage) income has significant contribution in household's gross income and a few households also have salaried income. The villages are accessible by public transport and tarred road and roads to fields are mostly untarred. The market for purchase and sale is about $5 \mathrm{~km}$ from both the villages. 


\section{Analytical Framework of the Study}

The analytical frame work is developed to assess the relationship between agriculture diversification, food self-sufficiency and food security. It is to be noted that the resource allocation towards cash crops and household food self-sufficiency are interdependent and affect each other. These decisions are taken simultaneously keeping in consideration the household food requirements.

Let Ybe the staple crop production

$\mathrm{X}$ is vector of exogenous variables that affect production decisions

$$
\text { Then } \mathrm{Y}=\mathrm{Y}(\mathrm{x})+\mathrm{e}_{1}
$$

Let $\mathrm{Y}^{\wedge}$ is the predicted staple crop production

$\mathrm{H}_{\text {fss }}$ is estimated household food self-sufficiency

FS is staple food stock at the beginning of the harvest period

CR is household staple food consumption requirements

$$
\text { Then } \mathrm{H}_{\mathrm{fss}}=\mathrm{Y}^{\wedge}+\mathrm{FS}-\mathrm{CR}
$$

If $\mathrm{Y}^{*}$ is the share of land allocated to cash crops

$\mathrm{Y}^{*}=\mathrm{Y}^{*}\left(\mathrm{X}, \mathrm{H}_{\mathrm{fss}}\right)+\mathrm{e}_{2}$

Under the null hypothesis that if household food self-sufficiency does not exert a significant effect on diversification into cash crop production, these terms will be significantly different from zero, implying that household can diversify into cash crops without any negative impact on food security. Assuming that all the unobserved factors are captured by explanatory variables, then we can specify the models for household i; as

$Y_{i}=X_{i} \beta+v_{i}$

Where, $\mathrm{Y}$ is share of land allocated by household i to cash crops

$\mathrm{X}$ is a vector of explanatory variables

$\beta$ is the vector of coefficients associated with the vector $\mathrm{X}$, and 


\section{International Journal of Social Science and Economic Research}

ISSN: $2455-8834$

Volume:05, Issue:08 "August 2020"

$v$ is the composite error term

We use equation (III) to specify the relationship between staple crop self-sufficiency and diversification into cash crops.

The food security measure based on formula is given by Thomson and Metz (1998). If the household's food entitlements are greater than its needs, it is classified as food secure and if household food needs are greater than entitlements the household is classified as food insecure. To estimate household food self-sufficiency requirements we use FAO's rule of $200 \mathrm{~kg}$ of refined cereal equivalent per capita per annum. The household food needs are estimated by multiplying per capita per annum requirements by the size of the household. While estimating the household food entitlements the household own production and household food expenditure as a percentage of income is taken into account.

Let FN be the household food needs and FE be the entitlements

$\mathrm{FN}=200 *$ Hsz, where Hsz is Household family size.

Let Hp be the households own production, then

Gap $=\mathrm{Hp}-\mathrm{FN}$, represents the gap in food security to be met as food expenditure from household income. Since average household food expenditure is around 53 percent of an average rural Indian's household consumption ${ }^{1}$. If this share of income meets the gap, then household is food secure. If the share of food expenditure falls short of gap, then household is food insecure. i.e.

If FE > FN, Household is food secure

If $\mathrm{FE}<\mathrm{FN}, \quad$ Household is food insecure

The diversification into cash crops is measured as the percentage share of land allocated to cash crops and also by using diversification index. The rice and wheat are taken as staple crops and crops other than these such as fruits, vegetables, oilseeds, etc. are taken as cash crops or high value crops. The diversification index is a measure of multiple agriculture productivity and the Simpson Index which has been used severally in the literature (Joshi et al., 2003; Minot et al., 2006) is used as a measure of diversification, as

$\mathrm{SID}=1-\sum_{\mathrm{i}=1}^{\mathrm{n}_{\mathrm{i}}} \mathrm{P}^{2}$

${ }^{1}$ https://www.business-standard.com/article/economy-policy/rural-india-tops-consumption-charts 114040300969_1.html 


\section{International Journal of Social Science and Economic Research}

ISSN: $2455-8834$

Volume:05, Issue:08 "August 2020"

Where $P_{i}$ is the proportionate area of the $i^{\text {th }}$ crop in gross area cultivated.

\section{Measurement of Key Variables}

The three main variables are agriculture diversification, food self-sufficiency and food security. In order to assess the food self-sufficiency of individual households we have converted the cereals into rice equivalent. The conversion is based on milling ratios and energy calories derived from the consumption of produce. Since rice and wheat are two main crops produced, the rice equivalent of wheat is presented as below.

$\begin{array}{cccc}\text { Crop } & \text { Calories } / \mathrm{kg} & \text { Milling ratio } & \text { Rice equivalent } \\ \text { Rice } & 3450 & 0.65 & 1 \\ \text { Wheat } & 3460 & 0.75 & 0.997\end{array}$

Based on the research question we hypothesize that a staple food self-sufficient household would diversify towards cash crops to a greater extent than a staple food deficient household. In other words staple food self-sufficiency will play a positive role and enhance diversification towards cash crops. Before testing the hypothesis we present the descriptive statistics of variables used in the analysis (Table 1).

Table 1: Descriptive Statistics of Variables

\begin{tabular}{|l|c|c|c|c|c|c|}
\hline Variable & \multicolumn{2}{|c|}{ Village I } & \multicolumn{2}{c|}{ Village II } & \multicolumn{2}{c|}{ Combined } \\
\hline & Mean & St.Dev & Mean & St.Dev & Mean & St.Dev \\
\hline Area under non-staples & 22.83 & 12.16 & 30.94 & 16.12 & 23.93 & 16.35 \\
\hline $\begin{array}{l}\text { Food self-sufficiency dummy } \\
(1=\text { food self-sufficient) }\end{array}$ & 0.48 & 0.502 & 0.84 & 0.368 & 0.66 & 0.47 \\
\hline Food security dummy (1=food secure) & 0.96 & 0.197 & 0.98 & 0.14 & 0.97 & 0.17 \\
\hline Marketing cost (Rs/kg/km) & 0.57 & 0.48 & 0.25 & 0.17 & 0.41 & 0.32 \\
\hline Distance to an all-weather road (km) & 1 & 0.01 & 1 & 0 & 1 & 0.01 \\
\hline Distance to main market outside Village & 1 & 0.01 & 1 & 0 & 1 & 0.01 \\
\hline Land rights measure (1= complete control) & 0.98 & 0.10 & 0.99 & 0.10 & 0.98 & 0.10 \\
\hline Credit access (1 = has access) & 0 & 0 & 0 & 0 & 0 & 0 \\
\hline Sex of farm manager (1= male) & 0.98 & 0.14 & 0.98 & 0.14 & 0.98 & 0.14 \\
\hline Household size & 7.97 & 2.78 & 10.47 & 6.75 & 9.26 & 5.26 \\
\hline Dependency ratio & 0.32 & 0.15 & 0.31 & 0.09 & 0.32 & 0.12 \\
\hline Age of farm manager & 48.35 & 10.33 & 55.75 & 7.44 & 52.05 & 9.72 \\
\hline $\begin{array}{l}\text { Education level of farm manager } \\
\text { (years of schooling) }\end{array}$ & 7.41 & 3.42 & 5.8 & 3.21 & 6.61 & 3.38 \\
\hline
\end{tabular}


International Journal of Social Science and Economic Research

ISSN: 2455-8834

Volume:05, Issue:08 "August 2020"

\begin{tabular}{|l|c|c|c|c|c|c|}
\hline $\begin{array}{l}\text { Total area under cultivation (farm size in } \\
\text { katha) }\end{array}$ & 44.04 & 39.30 & 93.04 & 51.98 & 69.26 & 52.24 \\
\hline $\begin{array}{l}\text { Share of non-farm income in total household } \\
\text { income (\%) }\end{array}$ & 73.05 & 22.17 & 63.10 & 21.32 & 68.07 & 22.26 \\
\hline Family Labour & 1.3 & 0.522 & 2.05 & 0.642 & 1.67 & 0.69 \\
\hline
\end{tabular}

Source: primary survey data

We also performed a two sample t-test to assess the land allocation to high value crops by food self-sufficiency status. The results are presented in Table 2.

Table 2: Household land allocation to high value crops by staple crop self-sufficiency status.

$\underline{\text { Percentage share of land allocated to high value crops }}$

\section{Staple crop-deficient Staple crop Self-sufficient $t$-statistic}

$\begin{array}{llll}\text { Village I } & 19.249(7.946) & 26.279(14.307) & 3.086^{*} \\ \text { Village II } & 18.33(4.123) & 29.268(9.643) & 4.850^{*} \\ \text { Combined } & 20.44(7.012) & 26.878(13.389) & 3.608^{*}\end{array}$

*Significant at $1 \%$ level

Fig. in parenthesis is standard deviation

It is observed that in both the villages the household that are self-sufficient in staples crop production allocate higher proportion of area to high value crops than households which are deficient in staples crop. Also the share of high value crops in area under cultivation is statistically significant.

The Food self-sufficiency and food security statistics in both the villages are summarized in Table 3 below. The figures indicate that village II has higher proportion of food self-sufficient household (84 percent). From the Table 2 it is shown that food self-sufficient households allocate higher proportion of resources towards cash crops. It implies that food self-sufficiency has a positive and favorable influence in resource allocation towards cash crops. 
International Journal of Social Science and Economic Research

ISSN: $2455-8834$

Volume:05, Issue:08 "August 2020"

Table 3: Food self-sufficiency and food security of Households (percentage)

\begin{tabular}{|l|c|c|c|}
\hline Households & Village I & Village II & Combined \\
\hline Food Self Sufficient & 48 & 84 & 66 \\
\hline Food Deficient & 52 & 16 & 34 \\
\hline Food Insecure & 4 & 2 & 3 \\
\hline Food Secure & 96 & 98 & 97 \\
\hline Chronic Food Deficient & 21 & 6 & 13.5 \\
\hline
\end{tabular}

*Chronic food deficient households are those whose own production is less than 50\% of their requirement

In both the village the percentage of food secure households is much higher than food selfsufficiency percentage. Since the methodology of assessing takes into account the income from other sources, it implies that households in both the villages have significant proportion of income from non-farm sources. The percentage share of non-farm income for Village I and II are 73.05 percent and 63.10 percent respectively. The non-farm income helps the household to meet the food requirements and improves food security status.

We formulate the hypothesis as:

Hypothesis I:

Null hypothesis: Staple food self-sufficiency does not influence diversification towards cash crops.

Alternate hypothesis: Staple food self-sufficiency influence diversification towards cash crops.

The staple food self-sufficient household would diversify towards cash crops to a greater extent than a staple food deficient household. We use regression analysis with land allocation towards cash crops as dependent variable and food self-sufficiency as one of the independent variables to test the Hypothesis I. The analysis is carried out separately for data obtained from both the villages and on combined data also.

The food self-sufficiency is a measure of gap in annual household food production and consumption requirements. The annual consumption requirements of households are measured as household size multiplied by $200 \mathrm{~kg}$ of refined cereal equivalent (FAO's Rule). If the production meets or exceeds the consumption requirements, the household is food self-sufficient otherwise its food deficient. The level of food self-sufficiency is measured as food self-sufficiency gap as a percentage of food consumption requirements of households. The variable food self-sufficiency 


\section{International Journal of Social Science and Economic Research}

ISSN: $2455-8834$

Volume:05, Issue:08 "August 2020"

level assumes the sign of positive or negative depending on self-sufficiency gap. The sign and magnitude of this variable determines the level of food self-sufficiency or deficiency.

\section{Analysis of Data}

Table 4 presents the analysis of data obtained from Village I and Village II. The variable Food Self-sufficiency Level has positive coefficient and is significant. Therefore the Null hypothesis that the staple food self-sufficiency does not influence diversification towards cash crops is rejected. It implies that staple food self-sufficient households have higher propensity to allocate more area towards high value crops than staple food deficient households. The results are consistent with the literature (Jayne, 1994).

Model Summary and ANOVA- Village I

\begin{tabular}{|c|c|c|c|c|c|}
\hline $\mathrm{R}$ & R Square & $\begin{array}{c}\text { Adjusted R } \\
\text { Square }\end{array}$ & $\begin{array}{c}\text { Std. Error of the } \\
\text { Estimate }\end{array}$ & F & Sig. \\
\hline .706 & .499 & .467 & 9.75874 & 15.430 & .000 \\
\hline
\end{tabular}

Model Summary and ANOVA- Village II

\begin{tabular}{|c|l|l|l|l|l|}
\hline $\mathrm{R}$ & \multicolumn{1}{|c|}{ R Square } & Adjusted R Square & $\begin{array}{c}\text { Std. Error of the } \\
\text { Estimate }\end{array}$ & \multicolumn{1}{|c|}{ F } & Sig. \\
\hline .770 & .592 & .566 & 10.61637 & 22.527 & .000 \\
\hline
\end{tabular}

Model Summary and ANOVA- Combined Data

\begin{tabular}{|l|l|l|l|l|l|}
\hline $\mathrm{R}$ & $\mathrm{R}$ Square & $\begin{array}{c}\text { Adjusted R } \\
\text { Square }\end{array}$ & $\begin{array}{c}\text { Std. Error of the } \\
\text { Estimate }\end{array}$ & $\mathrm{F}$ & Sig. \\
\hline .786 & .617 & .605 & 10.27318 & 51.874 & .000 \\
\hline
\end{tabular}

Table 4: Regression Analysis

\begin{tabular}{|l|c|c|c|c|c|c|}
\hline Variable & \multicolumn{2}{|c|}{ Village I } & \multicolumn{2}{c|}{ Village II } & \multicolumn{2}{c|}{ Combined Data } \\
\hline $\begin{array}{l}\text { Area Under HVC's } \\
\text { (Dependent Variable) }\end{array}$ & Coefficient & t-Values & Coefficient & t-Values & Coefficient & t-Values \\
\hline Constant & -7.995 & -0.838 & 1.786 & 0.161 & -3.409 & -0.495 \\
\hline $\begin{array}{l}\text { Food Self- } \\
\text { Sufficiency Level }\end{array}$ & .061 & $4.427^{*}$ & .036 & $5.037^{*}$ & .047 & $8.667^{*}$ \\
\hline
\end{tabular}

Source: primary survey data

$* 1 \%$ level of significance; ** 5\% level of significance; 


\section{International Journal of Social Science and Economic Research}

ISSN: $2455-8834$

Volume:05, Issue:08 "August 2020"

The analysis of data from Village II reveals almost similar results as that of Village I. The variable Food Self-sufficiency Level has positive coefficient and is significant at $1 \%$ level. Therefore the Null hypothesis that the staple food self-sufficiency does not influence diversification towards cash crops is rejected also for Village II.The analysis of combined data with sample size of 200 is presented in Table 4. The results of combined data are in confirmation to the separate analysis at village level. The Food Self-sufficiency Level has positive coefficient and is significant at $1 \%$ level. Therefore the Null hypothesis that the staple food self-sufficiency does not influence diversification towards cash crops is rejected for combined data also. It implies that staple food self-sufficiency has positive influence on household's allocation of resources towards high value crops. The staple food self-sufficient households allocate more area to high value crops than staple food deficient households. The results are consistent with the literature (Jayne, 1994).

\section{Conclusion}

The resource allocation towards cash crops and household food self-sufficiency are interdependent and affect each other. These decisions are taken simultaneously keeping in consideration the household food requirements. The subsistence cropping strategy is generally viewed as a food self-sufficiency strategy, guided by households concern for attainment of food security. Various empirical studies concluded that households in developing countries in order to maintain food security allocate significant resources to subsistence crops and then participate in high value crops or cash crops. The results of this study indicate food self-sufficiency households have higher propensity to allocate more area towards high value crops than staple food deficient households. It implies that household land allocation decisions are guided by the food security concerns and food self-sufficiency orfood security has favorable impact on land allocation decision towards high value crops. The agriculture households that are food self-sufficiency or food security have more tendencies to diversification towards high value or cash crops.

\section{References}

[1] Bhattacharyya, R., "Crop Diversification: A Search for an Alternative Income of the Farmers in the State of West Bengal in India". in Proceedings of International Conference on Applied Economics - ICOAE.2008.

[2] Birthal, P. S., Joshi, P.K, "Diversification in Indian Agriculture towards High-Value Crops: The Role of Smallholders".International Food Policy Research Institute, Discussion Paper 00727.2007. 


\section{International Journal of Social Science and Economic Research}

ISSN: $2455-8834$

Volume:05, Issue:08 "August 2020"

[3] Chand, R. "Diversification through high-value crops in Western Himalayan Region:

Evidence from Himachal Pradesh". Indian Journal of Agricultural Economics, 41(4), 652-663, 1996.

[4] De, U. K., \&Chattopadhyay, M., "Crop diversification by poor peasants and role of infrastructure: Evidence from West Bengal",Journal of Development and Agricultural Economics, Vol. 2(10), pp. 340-350, 2010.

[5] Featherstone,Allen M. \& Moss, Charles B., "Quantifying Gains To Risk Diversification Using Certainty Equivalence In A Mean-Variance Model: An Application To FloridaCitrus", Southern Journal of Agricultural Economics 22(02) · February, 1990.

[6] Govereh, J. and Jayne, T.S.,"Cash cropping and food crop productivity: synergies or tradeoffs?", Agricultural Economics 28, 39-50, 2003.

[7] Haque, T. Diversification of small farms in India: Problems and prospects. Small Farm Diversification: Problems and Prospects, National Centre for Agricultural Economics and Policy Research, New Delhi, 1996.

[8] Hayami, Yuziro\&Otsuka, K.,Beyond The Green Revolution: Agricultural Development Strategy Into The New Century. Agricultural Technology: Policy Issues for the International Community, World Bank, Wallingford, Oxon, UK. 1995.

[9] Ibrahim, H., \&Rahman, S. A., "Income and Crop Diversification among Farming Households in A Rural Area of North Central Nigeria". Journal of Tropical Agriculture, Food, Environment and Extension, Vol. 8, No.2, pp. 84 -89, ISSN 1119-7455, 2009.

[10] Jayne, T.S., "Do high food marketing costs constrain cash crop production: evidence from Zimbabwe".Economic Development and Cultural Change 42, 387-402, 1994.

[11] Jha, B., Tripathi, A., \&Mohanty, B. , "Drivers of Agricultural Diversification in India, Haryana and the Greenbelt Farms of India”.Working Paper Series No.E/303/2009.

[12] Joshi, P. K., Birthal, P. S., \& Minot, N., "Sources of Agricultural Growth in India: Role of Diversification towards High-Value Crops".International Food Policy Research Institute, MTID, Discussion Paper No. 98.(2006).

[13] Mukherjee, S. ,"Crop Diversification and Risk: An Empirical Analysis of Indian State". Munich Personal RePEc Archive (MPRA), Paper No. 35947, Centre for Development Studies, India 2012. 
[14] Pingali, P. L., \&Rosegrant, M. W. , "Agricultural Commercialization and Diversification: Processes and Policies.”Food Policy, Vol.20, No.3, pp. 171-185, 1995.

[15] Sati P. V., "Agricultural Diversification in the Garhwal Himalaya: A Spatio-Temporal Analysis".Sustainable Agriculture Research, Vol. 1, No. 1.2012.

[16] Singh, K. A, "Crop Diversification and Agricultural Growth in Bihar: District-Wise Analysis".Growth and Diversification of Agriculture, 254-261, 2008.

[17] Von Braun, J.,"Production, employment, and income effects of commercialization of agriculture". In: Von Braun, J. and Kennedy, E. (eds) Agricultural Commercialization, Economic Development, and Nutrition, Johns Hopkins University Press, Baltimore, Maryland, pp. 37-64, 1994. 